\title{
STRATEGI KOMUNIKASI PUSTAKAWAN DAN PEMUSTAKA DALAM MENCARI SUMBER INFORMASI DI PERPUSTAKAAN
}

\author{
Armen \\ Pustakawan IAIN Imam Bonjol Padang \\ e-mail : armenarfat@gmail.com
}

\begin{abstract}
From a religious perspective, we can easily answer that it is God who teaches us to communicate, using the intellect and language skills that are bestowed upon us. The Qur'an says, "God is most gracious, who has taught the Qur'an. He created man, who taught him how to speak "(Ar-Rahman: 1-4). Speaking of communication definitions, there is no right or wrong definition. Like any model or theory, definitions must be seen from their usefulness to explain the phenomena that are defined and evaluate them. Maybe too narrow, for example "Communication is the delivery of messages through electronic media or too broad for example Communication is the interaction between two or more living things". Communication is broadly defined as sharing experiences to some extent, each being can be said to communicate in terms of sharing experiences. Human communication in English is Human communication. All Beings, institutions or institutions large and small all need good communication.
\end{abstract}

Keywords: Improving Librarian Communication with Librarians in Finding Sources of Information

\begin{abstract}
Abstrak : Dari perspektif agama, secara gampang kita bisa menjawab bahwa Tuhan-lah yang mengajari kita berkomunikasi, dengan mengunakan akal dan kemampuan berbahasa yang dianugerahkan-Nya kepda kita. Al-Qur'an mengatakan, "Tuhan Yang Maha Pemurah, yang telah mengajarkan Al-Qur'an. Dia menciptakan manusia, yang mengajarinya pandai berbicara" (Ar-Rahman:1-4). Berbicara tentang defenisi komunikasi, tidak ada defisi yang benar atau salah. Seperti juga model atau teori, definisi harus dilihat dari kemanfaatannya untuk menjelaskan fenomena yang didefinisikan dan mengevaluasinya. Mungkin terlalu sempit, misalnya "Komunikasi adalah penyampaian pesan melalui media elektronik atau terlalu luas misalnya Komunikasi adalah interaksi antara dua makhluk hidup atau lebih". Komunikasi didefinisikan secara luas sebagai berbagi pengalaman sampai batas tertentu, setiap makhluk dapat dikatakan melakukan komunikasi dalam pengertian berbagi pengalaman. Komunikasi manusia dalam bahasa Inggris adalah Human comunication. Semua Makhluk, lembaga atau instansinya Besar maupun kecil semua butuh komunikasi yang baik.
\end{abstract}

Kata kunci : Meningkatkan Komunikasi Pustakawan dengan Pemustaka dalam Mencari Sumber Informasi

\section{A. KOMUNIKASI}

Komunikasi adalah suatu proses dimana dua orang atau lebih membentuk atau melakukan pertukaran informasi dengan satu sama lainnya, yang pada gilirannya akan tiba pada saling pengertian yang mendalam (D. Lawrence Kincaid, 1981 : Hal.22).
Komunikasi adalah proses dimana suatu ide dialihkan dari sumber kepada satu penerima atau lebih dengan maksud untuk mengubah tingkah laku mereka (Everett M. Rogers). Unsurunsur komunikasi menurut Joseph de Vito, K. Sereno dan Erika Vora, Pertama. Sumber peristiwa, komunikasi akan melibatkan sumber 
sebagai pembuat atau pengiriman informasi. Dalam komunikasi antar manusia, sumber bisa terdiri dari satu orang, tetapi bisa juga dalam bentuk kelompok misalnya partai, organisasi atau lembaga. Sumber sering disebut pengiriman, komunikator atau dalam bahasa Inggrisnya disebut source, sender, atau encoder. Kedua. Pesan yang dimaksud dalam proses komunikasi adalah suatu yang disampaikan pengiriman kepada penerima. Pesan dapat disampaikan dengan cara tatap muka atau melalui media komunikasi. Isinya bisa berupa ilmu pengetahuan, hiburan, informasi, nasihat atau propoganda. Dalam bahasa Inggris pesan biasanya diterjemahkan dengan kata mesage, content atau information. Ketiga. Media adalah alat yang digunakan untuk memindahkan pesan dari sumber kepada penerima. Berkat perkembangan teknologi komunikasi khususnya bidang komunikasi masa elektronik yang begitu cepat, media mengaburkan batas-batas untuk membedakan antara media komunikasi dan komunikasi antar pribadi. Hal ini disebakan karena makin cangihnya media komunikasi itu sendiri yang bisa dikombinasikan (multimedia) antar satu sama lainnya. Selain media komunikasi seperti diatas, kegiatan dan tempat-tempat tertentu yang banyak ditemui dalam masyarakat pedesaan, bisa juga dipandang sebagai media komunikasi sosial, misalnya rumahrumah ibadah, balai desa, arisan, pangung kesenian dan pesta rakyat. Keempat. Penerima adalah pihak yang menjadi sasaran pesan yang dikirim oleh sumber. Penerima bisa terdiri dari satu orang atau lebih bisa bentuk kelompok, partai atau Negara. Penerima biasa disebut dengan berbagai macam istilah seperti khalayak, sasaran, komunikan, atau dalam bahasa Inggris disebut audince atau reciver. Kelima, Pengaruh adalah perbedaan antara apa yang dipikirkan, dirasakan dan dilakukan oleh penerima sebelum dan sesudah menerima pesan. Keenam. Tangapan balik adalah salah satu bentuk dari pada pengaruh yang berasal dari penerima. Misalnya sebuah konsep sebuah konsep surat yang memerlukan perubahan sebelum dikirim, atau alat yang digunakan untuk menyampaikan pesan itu mengalami gangguan sebelum sampai ke tujuan. Ketujuh. Lingkungan adalah faktor-faktor tertentu yang dapat mempengaruhi jalannya komunikasi. Dari uraian diatas setiap unsur memiliki peranan yang sangat penting dalam membangun proses komunikasi, saling bergantung sama lainya, tanpa keikutsertaan satu unsur akan mempengaruhi jalannya komunikasi. Terciptanya pendidikan sepanjang hayat (Long life education).

\section{B. LANGKAH - LANGKAH PUSTA- KAWAN DALAM MEMBERIKAN SUMBER INFORMASI}

Pustakawan adalah orang yang bekerja pada lembaga-lembaga perpustakaan atau yang mengelola perpustakaan tersebut dan memiliki pendidikan perpustakaan secara formal. Pustakawan merupakan pejabat fungsional yang berkedudukan sebagai pelaksana penyelenggara tugas utama kepustakawanan pada unit-unit perpustakaan, dokumentasi dan informasi pada instansi pemerintah. Pustakawan harus mampu memberikan informasi kepada Pemustaka, juga bagaimana cara menarik pemustaka untuk selalu ingin datang ke Perpustakaan dalam rangka mencari 
sumber informasi yang dibutuhkan, tentu bermacam cara yang harus dilakukan seorang pustakawan sehingga pemustaka senang datang ke Perpustakaan. Salah satu menumbuhkan minat baca pemustaka.

Menurut Tjipranoto(1995).
Melihat tantangan masa depan,
peluang yang ada, masalah yang akan
dihadapi Perpustakaan. Kualitas
pustakawan masa akan datang dalam
memberikan informasi diharapkan
sebagai berikut:

1.Memiliki kemampuan berkomunikasi sehingga dapat dengan mudah mengidentifikasi keperluan pemakai.

2.Memiliki kemampuan teknis dibidang perpustakaan dengan pendidikan Alhi Madya (D.3) dibidang Perpustakaan, Dokumentasi dan Informasi.

3.Bisa berbahasa asing khususnya bahasa Inggris untuk mempermudah hubungan dengan dunia Internasional.

4.Mampu mengembangkan teknis dan prosedur kerja dibidang perpustakaan.

5.Mampu memanfaatkan ilmu pengetahuan dan teknologi untuk keperluan pengembangan perpustakaan.

6.Mampu melaksanakan penelitian dibidang perpustakaan, dokumentasi dan informasi secara mandiri.

7.Kemampuan untuk berorientasi kepada keperluan pemustaka. Petugas diperpustakaan dapat memenuhi keperluan pemakai dalam mencari informasi, bukan mempersulit untuk mendapatkan informasi.
Kepuasaan bagi Pustakawan adalah bisa memberikan informasi secara cepat, tepat dan akurat. Kekecewaan bagi seorang Pustakawan apabila tidak dapat memberikan informasi kepada pemustaka sesuai dengan apa yang diinginkanya. Pemustaka tidak akan puas apabila tidak mendapatkan informasi yang dibutuhkan. Pustakawan harus bisa menyenangkan permustaka serta memberikan daya tarik dengan berbagai macam-macam informasi yang bisa disajikan agar pemustaka senang berkunjung ke Perpustakaan. Maka perlu Komunikasi yang baik antara Pustakawan dan Pemustaka akan menghasilkan Palayanan yang baik dan menghasilkan informasi yang baik. Pustakawan perlu meningkatkan komunikasi dengan Pemustaka sehingga besinergi untuk mendapatkan sumber informasi. Pemustaka adalah User (Pengguna) sedang Pustakawan adalah Pelayan dan Penyedia Informasi. Untuk meningkatkan komunikasi perlu kerja sama yang baik antara Pustakawan dan Pemustaka. Apabila terjadi Miss Komunikasi antara Pustakawan dan Pemustaka akan berkakibat fatal bagi kedua belah pihak untuk itu harus meningkatkan komunikasi yang baik.

\section{FUNGSI INFORMASI}

Informasi adalah adalah suatu rekaman fenomena yang diamanati, atau bisa juga berupa putusan-putusan yang dibuat seseorang (Estabrook, 1977 : 245). Sebuah peristiwa yang mengemparkan terjadi di suatu daerah, yaitu beberapa orang penduduknya tewas keracunan tempe. Ini sebuah fenomena, dan menjadi informasi jika ada orang melihatkan atau menyaksikan, bahkan mungkin 
merekamnya. Hasil kesaksian atau rekaman dari orang yang melihat atau menyaksikan peristiwan atau fenomena tadi itulah yang dimaksud informasi. Informasi lebih bermakna berita. Berita adalah bentuk dari pesan-pesan komunikasi. Salah contoh lagi tadi malam kita bermimpi yang sangat berkesan, misalnya mendapat hadiah sebuah mobil mewah dari undian sebagai nasabah sebuah bank multinasional. Mimpi itu kita sebut sebuah fenomena atau peristiwa (terlepas mimpi itu betul atau bohongan). Apabila kita ceritakan kepada orang tentang mimpi tadi itu sudah ada nilai informasi. Informasi yang mengandung makna sejarah ini penting waktu yang akan datang karena merupakan data dan fakta sejarah. Di perpustakaan dan kelembagaan informasi lainnya, organisasi informasi agar menentukan keberhasilan pemanfaatannya. Misalnya, melalui indeks kita bisa dengan cepat menemukan informasi yang kita cari di suatu tempat di perpustakaan atau di situs-situs internet. Fungsi informasi beragam pula karena akan bergantung pada manfaatnya bagi setiap orang yang kebutuhannya berbeda-beda. Demikian fungsinya bagi suatu organisasi, ia akan disesuaikan dengan jenis organisasi yang bersangkutan. Dalam organisasi sekolah atau pada lembagalembaga pendidikan pada umumnya, informasi yang bermanfaat adalah yang banyak mendukung tugas-tugas lembaga tersebut, semua jenis informasi yang mempunyai aspek edukatif, riset dan reakreatif. Informasi lain juga diperlukan, tetapi tidak menonjol. Didalam lingkungan keluarga informasi dan sumber-sumber informasi sangat berguna keberadaannya. Buku, Majalah, Surat Kabar, Radio, Televisi, Komputer, bahkan internet semuanya bermanfaat bagi pengembangan wawasan anggota keluarga. Bagi kita yang penting informasi itu bermacam-macam jenis fungsi, juga manfaatnya, karena hampir tidak seorangpun yang tidak membutuhkan informasi walau sekecil apapun kebutuhan tersebut. Misalnya seorang bayi yang baru lahir pun sebenarnya membutuhkan "informasi". dari ibunya sehingga ia menangis lantas ibunya datang sambil mengusapusap dan membobokannya, sang bayi pun diam, mendengarkan dan tentu saja merasakan adanya sentuhan lembut ibunya tadi. Mengenal dan kemudian mengerti tentang suatu benda yang berada dihadapannya pun telah termasuk kedalam konsep informasi karena adanya pemahaman yang masuk kedalam pikiranya, walau hal itu hanya merupakan contoh yang sangat sederhana. Tidak ada cara lain memang kecuali membernarkan bahwa informasi itu banyak gunanya bagi manusia. Dan memang pada kenyataannya seluruh aspek kehidupan manusia itu membutuhkan informasi, informasi yang diharapkan dapat menunjang peningkatan pola kehidupannya, kehidupan yang terusmenerus menuju kompleksitas yang semakin meninggi.

\section{SUMBER-SUMBER INFORMASI}

Sebenarnya informasi ini ada dimana-mana, di pasar, sekolah rumah, lembaga-lembaga suatu organisasi komersial, buku-buku, majalah, surat kabar, dan juga perpustakaan atau tempat-tempat lain. Pokoknya, di mana suatu benda atau peristiwa berada, di sana bisa timbul informasi. Khusus informasi yang bersifat ilmiah yang 
dapat dimanfaatkan untuk kepentingan penelitian dan ilmu pengetahuan, banyak terdapat pada rekaman atau tulisan ilmiah, baik yang tersimpan pada literatur primer, sekunder maupun tersier. Buku, majalah, surat kabar, majalah ilmiah termasuk juga media bukan hasil cetakan seperti film, microfilm, film strip, video tape, media audio, merupakan sumber informasi ilmiah meskipun ada juga sebagian informasinya yang tergolong bukan ilmiah seperti informasi tentang berita keluarga, berita kematian, dan iklan komersial.

Semua jenis informasi tersebut, baik yang tergolong ilmiah maupun yang non-ilmiah, terutama yang telah disimpan dalam rekaman tersebut, sebagian besar disimpan di perpustakaan. Sebagaimana diketahui konsep perpustakaan merupakan pengelolaan informasi yang tampak dalam kegiatan penghimpunan, pengolahan, dan penyebarluasan informasi untuk kepentingan masyarakat banyak. Karena unsur pemanfaatannya dilakukan secara berulang dan terus menerus, maka segi-segi keawetan dan pemerataannya sangat diperhatikan oleh perpustakaan, dan oleh karena itu di sini berlaku fungsi pelestari informasi dari perpustakaan, yang kemudian berkembang menjadi fungsi untuk melestarikan hasil budaya bangsa.

Di tempat lain juga ada kegiatan pengelolaan informasi, tetapi tentu mempunyai misi dan tujuan yang berbeda dengan perpustakaan, bahkan ada yang bertujuan untuk mencari keuntungan materi seperti terjadi pada organisasi-organisasi komersial dan atau perdagangan. Sementara itu organisasi perpustakaan hingga saat ini masih bersifat sosial. Penyebaran dan pemanfaatan informasi seluasluasnyalah yang menjadi tujuan perpustakaan pada umumnya. Perpustakaan sebagai pusat sumber informasi dapat dikelompokkan ke dalam beberapa jenis yang masingmasing mempunyai ciri dan penekanan fungsi yang berbeda. Ada yang berfungsi untuk melayani kebutuhan informasi bagi segenap anggota masyarakat luas secara menyeluruh ada yang berfungsi melayani kebutuhan informasi bagi kelompok masyarakat khusus seperti masyarakat peneliti saja atau masyarakat ilmuwan saja, atau masyarakat sekolah saja dan ada juga ada juga yang bertugas khusus melayani kebutuhan masyarakat dalam lingkungan organisasi khusus. Sumber-sumber informasi dari berbagai jenis dan bentuk itu tersebar dan dikelola oleh perpustakaan sesuai jenis perpustakaan yang mengelolah yaitu sekolah, perguruan tinggi, perpustakaan khusus, dan umum. Di samping itu, ada juga perpustakaan nasional, daerah, daerah tingkat kabupaten dan kota, perpustakaan desa, komunitas, dan perseorangan (pribadi). Semua jenis perpustakaan ini berfungsi sebagai tempat dan sekaligus sebagai pusat pengelolaan dan penyebarluasan informasi untuk kepentingan masyarakat yang mebutuhkan.

\section{E. PERANAN PERPUSTAKAAN}

Secara Umum peranan Perpustakaan dapat menjadi media antara pemakai koleksi sebagai sumber informasi pengetahuan, menjadi lembaga pengembangan minat dan budaya membaca serta pembangkit kesadaran pentingnya belajar 
sepanjang hayat. Mengembangkan komunikasi antara pemakai atau dengan penyelenggara sehingga tercipta kolaborasi, sharing pengetahuan maupun komunikasi ilmiah lainnya. Motivator, mediator dan fasilitator bagi pemakai dalam usaha mencari, memanfaatkan dan mengembangkan ilmu pengetahuan dan pengalaman, berperan sebagai agen perubahan, pembangunan dan kebudayaan manusia. Tugas perpustakaan adalah : Setiap perpustakaan memiliki kewajiban yang sudah ditentukan dan direncanakan untuk dilaksanakan. Tugas setiap jenis perpustakaan berbeda-beda sesuai dengan kewajiban yang ditetapkan. Perpustakaan merupakan salah satu sumber informasi bagi pemustaka, perpustakaan juga sebuah ruangan atau gedung digunakan untuk menyimpan buku dan terbitan lainnya yang biasanya disimpan menurut tata susunan tertentu yang digunakan pembaca bukan untuk dijual (SulistyoBasuki:1991). Ada dua unsur dalam perpustakaan, yaitu buku dan ruangan. Namun pada zaman sekarang ini, koleksi sebuah perpustakaan tidak hanya sebatas berupa buku-buku tetapi bisa berupa bahan non buku seperti Film, Slide, CD, Micro Film, DVD, Flasdisk dan lainnya, yang dapat disimpan diperpustakaan sebagai sumber informasi. Kemudian semua informasi ini diorganisir, disusun teratur, sehingga kita butuh suatu informasi akan cepat dan mudah untuk menemukannya. Perpustakaan merupakan kumpulan buku, manuskrip, dan bahan pustaka lainnya yang digunakan untuk keperluan studi atau bacaan. Dalam hal lain disebutkan bahwa perpustakaan merupakan kumpulan buku atau akomodasi fisik buku dikumpulkan. Perkembangan ilmu pengetahuan menjadikan koleksi yang beragam didukung oleh perangkat teknologi modern. Perpustakaan modern menyediakan ruangan lain yang tak ada pada perpustakaan tradisional seperti ruangan audio visual. Perpustakaan modern juga menyediakan fasilitas internet baik dalam bentuk komputer maupun hot area. Dari uraian diatas dapat disimpulkan bahwa perpustakaan adalah suatu unit kerja yang berupa tempat menyimpan koleksi pustaka yang datur secara sistematis dan dapat digunakan oleh pemakai (user) sebagai sumber informasi. Perpustakaan sebagai lembaga yang mengelola sumber informasi dan pelestarian bahan pustaka hasil budaya bangsa serta melakukan jasa informasi perlu dipersiapkan dan dikelola dengan baik agar dapat berfungsi dengan sistem perpustakaan yang kompetitif sehingga pada akhirnya bermuara kepada kepuasaan pemustaka.

Menurut Undang-undang perpustakaan Nomor 43 tahun 2007 tentang Perpustakaan pada Bab I dan ayat 1 menyatakan Perpustakaan adalah institusi pengelola koleksi karya tulis, karya cetak, dan karya rekam secara professional dengan sistem yang baku guna memenuhi kebutuhan pendidikan, penelitian, pelestarian informasi dan reakreasi para pemustaka.

Perkembangan perpustakaan menjadi sumber informasi ilmu pengetahuan, teknologi dan budaya. Dari istilah pustaka berkembang istilah pustakawan, kepustakaan, ilmu 
perpustakaan dan kepustakawan yang akan dijelaskan sebagai berikut :

1. Pustakawan : orang yang bekerja pada lembaga-lembaga perpustatakaan atau yang mengelola perpustakaan tersebut dan memiliki pendidikan perpustakaan secara formal.

2. Kepustakaan : Bahan-bahan yang menjadi acuan atau bacaan dalam menghasilkan atau menyusun tulisan baik berupa artikel, karangan, buku, laporan dan sejenisnya.

3. Ilmu Perpustakaan : Bidang ilmu yang mempelajari dan mengkaji hal-hal yang berkaitan dengan perpustakaan baik dari segi organisasi koleksi, penyebaran dan pelestarian ilmu pengetahuan teknologi dan budaya serta jasa-jasa lainnya kepada masyarakat, hal lain yang berkenaan dengan jasa perpustakaan dan peranan secara lebih luas.

4. Kepustakawan : adalah hal-hal yang berkaitan dengan upaya penerapan ilmu perpustakaan dan profesi kepustakawanan.

Aktifitas utama dari perpustakaan adalah menghimpun informasi dalam berbagai bentuk atau format untuk pelestarian bahan pustaka dan sumber informasi, sumber ilmu pengetahuan lainnya. Maksud pendirian perpustakaan adalah untuk menyediakan sarana atau tempat untuk menghimpun berbagai sumber informasi untuk dikoleksi secara terus menerus, diolah dan diproses, sebagai sarana wahana untuk melestarikan hasil budaya manusia (ilmu pengetahuan, teknologi dan budaya) melalui aktifitas pemeliharaan dan pengawetan koleksi.
Sebagai agen perubahan (Agen of changes) dan agen kebudayaan serta pusat informasi dan sumber belajar mengenai masa lalu sekarang dan masa yang akan datang, juga menjadi pusat penelitian, reakreasi dan aktifitas ilmiah lainnya. Perpustakaan tentu perlu menyediakan sarana dan prasarana seperti AC, Internet, Wifi, dan fasilitas lainnya, sehingga membuat pengunjung tertarik untuk datang ke Perpustakaan.

Kegiatan di Perpustakaan

\section{F. FUNGSI PERPUSTAKAAN}

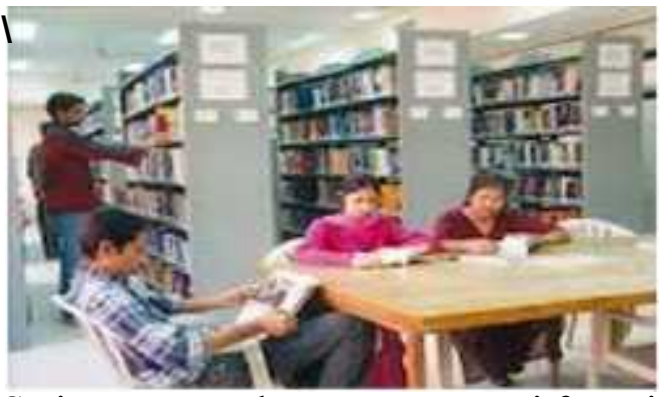

Setiap perpustakaan mempunyai fungsi diantaranya adalah :

1. Fungsi Penyimpanan, bertugas menyimpan koleksi (informasi) karena tidak mungkin semua koleksi dapat dijangkau oleh perpustakaan.

2. Fungsi Informasi, perpustakaan berfungsi menyediakan berbagai informasi untuk masyarakat.

3. Fungsi Edukatif : perpustakaan menjadi tempat dan menyediakan sarana untuk belajar baik dilingkungan formal maupun non formal.

4. Fungsi Reakreasi, masyarakat dapat menikmati reakreasi, kultural dengan membaca novel, cerita rakyat, puisi dan sebagainya.

5. Fungsi Kultural, perpustakaan berfungsi untuk mendidik dan mengembangkan apresiasi budaya masyarakat melalui berbagai 
aktifitas, seperti: pameran, pelayanan harus saling hormatpertunjukan, bedah buku, menghormati.

mendongeng, seminar, dan sebagainya.

Saran, Pustakawan dan Pemustaka harus saling kerja sama yang baik dalam menjalin komunikasi

\section{G. MENINGKATKAN KEAHLIAN PUSTAKAWAN}

Dalam rangka meningkatkan keahlian Pustakawan perlu langkahlangkah secara profesional melalui, sebagai berikut :

a. Pendidikan dan Latihan (Diklat)

b. Mengikuti Seminar

c. Workshop

d. Banyak Membaca

e. Mengikuti Informasi Berita yang setiap waktu selalu berubah

f. Menguasai Bahasa Inggris dan Bahasa Arab

Demikianlah Tulisan ini disusun yang jauh dari kesempurnaan, paling tidak mendapatkan gambaran bahwa kita perlu perlu menjalin komunikasi. Untuk itu saya membutuhkan kritikan dan saran yang sifat membangun demi menghasilkan informasi yang lebih baik.

\section{KESIMPULAN DAN SARAN}

Kesimpulan, Pustakawan sangat menentukan kemajuan sebuah perpustakaan. Seseorang pustakawan harus (profesional) terlatih, punya keahlian dan rasa tanggung jawab yang tinggi terhadap kinerja, memperhatikan mutu hasil kinerja yang dicapai. Pustakawan harus menjadi pelayan yang baik bagi pemustaka, serta menyadari tugasnya sebagai penyedia informasi. Pemustaka juga harus bisa menghormati tugas dari seorang pustakawan dalam memberikan untuk dapat menghasilkan informasi yang dibutuhkan dan mendapatkan pelayanan yang baik, dan harus menyadari tugas dan tanggung jawab masing-masing.

\section{DAFTAR KEPUSTAKAAN}

Ari Suryandari, Perpustakaan Digital, Jakarta : CV. Sagung Seto, 2007

B. Uno Hamzah, Teknologi Komunikasi dan Informasi Pendidikan, Jakarta : Bumi Aksara, 2003

Cangara Hafied, Pengantar Ilmu Komunikasi, Jakarta : Rajagrafindo Persada, 2008

Darmono, "Manajemen dan Tata Kerja Perpustakaan Sekolah” Jakarta : Grasindo, 2001

Morissan, Teori Komunikasi, Jakarta : Prenada Media Group, 2013

Kamus Besar Bahasa Indonesia. Jakarta : Balai Pustaka :1990, h. 117

Permadi Agus, Winisis Untuk Pustakawan Dokumentalis Arsiparis, Jakarta : PDII, 2001

- Ns. Sutarno, Manajemen Perpustakaan. Jakarta : Samitra Media Utama.2004

- Mulyana Deddy, Ilmu Komunikasi Suatu Pengantar" 
Jakarta : PT. Remaja Rosdakarya,2005

Sulistyo-Basuki. Pengantar Ilmu Perpustakaan. Jakarta : Garmedia Pustaka: 2004

Supriyanto Aji, Pengantar Teknologi Informasi, Jakarta : Salemba Infotek, 2007

Tjipranoto, Fandy, Strategi Pemasaran, Yogyakarta : Andi Offset, 1995 hal.210

Undang-Undang Perpustakaan

Republik Indonesia, No. 43

Tahun 2007

Yusuf Pawit, Ilmu Informasi, Komunikasi, dan Kepustakaan, Jakarta, Bumi Aksara, 2013

Yusuf Pawit, Teori dan Praktik Penelusuran Informasi, Jakarta, Kencana, 2010 